\title{
THE RECENT CONSTITUTIONAL AMENDMENTS
}

The present year has witnessed the incorporation in our National Constitution of two important changes to be known respectively as the Sixteenth and Seventeenth Amendments;the one, proclaimed by the Secretary of State as formally adopted February 25, 1913, empowers Congress to lay a direct tax in the nature of an income tax irrespective of the source whence such income may be drawn, and freed, too, from any necessity of apportionment among the several states in conformity to their population; the other, proclaimed May 31, 1913, transfers the choice of senators from state legislatures directly to the voters. As in the instance of the adoption in 1798 of the Eleventh Amendment, a constitutional interpretation rendered by the Supreme Court has furnished the impulse leading to the adoption of the Sixteenth. The Seventeenth Amendment, however,-a change long-desired by many-draws its inspiration from widely-differing sources and is fraught with far deeper constitutional significance. Here we have our second nationail legislative chamber brought to rest directly on the will of the citizen-body, and thus, bearing in mind that the National Executive is now practically although not constitutionally chosen by popular vote, our plan of government is seen to be divested of that element of official guardianship deemed essential when in 1787 , it was sought to interpose local legislators or Federal electors between the people at large and those who should be selected to administer their government. Time, however, has effectualy demonstrated the peril or ineffectiveness of such intermediates, nor is the spirit of modern self-government easily tolerant, as may be gathered from recent discussions in the British and French parliaments, of legislators whose immediate choice is not confided to the hands of those for whose benefit it is supposed to have been made. Viewed from the strictly constitutional standpoint it cannot be said that the first of these additions to our organic law ofters features of special interest;-its value is plainly economic in character. By virtue of it our national legislature simply acquires that practical freedom from restraint in an all-important aspect of raising national revenue which normally belongs to the modern parliamentary body but which the spirit of caution or timidity led our constitutional forefathers to seriously narrow in the light of 
present day economic needs; the second of these changes, however, we shall find in complete harmony with the direction. now finally taken in modern political experience by those forces which are swiftly bringing the true sovereign elements in every constitutional organization into a position of deserved control. It is thus of the first constitutional importance and merits our most careful attention.

We proceed to consider briefly, then, the course of opinion which has led to the ratification of the Sixteenth Amendment, placing in the margin for convenience of reference a transcript of the actual steps taken in Congress and a state legislature on the formal adoption of the measure. ${ }^{1}$

1 A joint resolution proposing a constitutional amendment permitting Federal taxation of income was recommended to Congress by President Taft in a special message, June 16, 1909. Congress having complied with the recommendation, passed the following resolution July 27, 1909:

"Resolved by" the Senate (the House of Representatives concurring), That the President of the United States be requested to transmit forthwith to the executives of the severa! states of the United States copies of the article of amendment proposed by Congress to the state legislatures to amend the Constitution of the United States, passed July twelfth, nineteen hundred and nine, respecting the power of Congress to lay and collect taxes on incomes, to the end that the said states may proceed to act upon the said article of amendment; and that he request the executive of each state that may ratify said amendment to transmit to the Secretary of Statc a certified copy of such ratification."

Following is the text of the resolution:

S. J. Res. 40. Sixty-first Congress of the United States of America, at the first session, begun and held at the city of Washington on Monday, the fifteenth day of March, one thousand nine hundred and nine.

Joint Resolution proposing an amendment to the Constitution of the United States.

Resolved by the Senate and House of Representatives of the United States of America in Congress assembled (two-third of each House concurring therein), That the following article is proposed as an amendment to the Constitution of the United States, which, when ratified by the legislatures of three-fourths of the several States, shall be valid to all intents and purposes as a part of the Constitution:

Article XVI. The Congress shall have power to lay and collect taxes on incomes, from whatever source derived, without apportionment among the several states, and without regard to any census or enumeration.

$$
\text { J. G. CANNON, }
$$

Speaker of the House of Representatives.

J. S. SHERMAN,

Vice-President of the United States and President of the Senate.

Attest: A. McDOWELL, Clerk of the House of Representatives. 
"The constitutional provisions respecting Federal taxation," said Mr. Justice, now Mr. Chief Justice White, in the leading case of Pollock v. Farmers Loan \& Trust Co. (decided April 8, 1895), "are four in number and are as follows:

" 1 . Representatives and direct taxes shall be apportioned among the several states which may be included within this Union, according to their respective numbers, which shall be determined

$$
\text { CHARLES G. BENNETT, Secretary. }
$$

By HENRY H. GILFRY, Chief Clerk.

I certify that this joint resolution originated in the Senate.

CHARLES G. BENNETT, Secretary. By HENRY H. GILFRY, Chief Clerk.

An enrolled copy of this joint resolution was deposited with the Secretary of State July 31,1909, and by him transmitted to the governors of the several states.

The State of Nebraska subsequently passed the following resolution, which was in due course reported to Congress and the Department of States:

"Whereas both houses of the Sixty-first Congress of the United States of America, at its first session, by a constitutional majority of two-thirds thereof, made the following proposition to amend the Constitution of the United States of America in the following words, to wit:

"'A joint resolution proposing an amendment to the Constitution of the United States.

"'Resolved by the Senate and House of Representatives of the United States of America in Congress assembled (two-thirds of each house concurring therein), That the following article is proposed as an amendment to the Constitution of the United States which, when ratified by the legislatures of three-fourths of the several states, shall be valid to all intents and purposes as a part of the Constitution, namely-

"“" Art. XVI. The Congress shall have power to lay and collect taxes on incomes, from whatever source derived, without apportionment among the several states, and without regard to any. census or enumeration." "

"Therefore

"Be it enacted and resolved by the Legislature of the State of Nebraska, that the said proposed amendment to the Constitution of the United States of America be, and the same is hereby ratified by the Legislature of the State of Nebraska.

"Sec. 2. Be it further resolved, that certified copies of this joint resolution be forwarded by the Governor of this State to the Secretary of National Congress.

"JOHN KUHL, "Spcaker of House of Representatives.

"Attest: HENRY C. RICHMOND,

"Chief Clerk of House of Representatives.

"M. R. HOPEWELL,

"President of Senate. 
by adding to the whole number of free persons, including those bound to service for a term of years and excluding Indians not taxed, three-fifths of all other persons.' Art. I, sec. 2, clause 3. (The Fourteenth Amendment modified this provision, so that the whole number of persons in each state should be counted, "Indians not taxed" excluded.)

" '2. The Congress shall have power to lay and collect taxes, duties, imposts, and excises, to pay the debts and provide for the

State at Washington and to the presiding officers of each House of the

"Attest: WM. H. SMITH,

"Secretary of Senate.

"Approved, 1911. "CHESTER H. ALDRICH, "Governor.

"State of Nebraska, ss:

"I, Henry C. Richmond, chief clerk House of Representatives, hereby certify that the within bill originated in the House and passed the Legislature on the 9th day of February, 1911.

"HENR.Y C. RICHMOND, "Chief Clerk House of Representatives. "STATE OF NEBRASKA.

"Office of Secretary of State.

"I Addison Wait, Secretary of State of the State of Nebraska. do hereby certify that I have carefully compared the annexed copy of House Roll No. 55, enacted and passed by the thirty-second session of the Legislature of the State of Nebraska, with the enrolled bill on file in this office, and that the same is a true and correct copy of said House Roll No. 55.

"In testimony whereof, I have hereunto set my hand and affixed the great seal of the State of Nebraska.

"Done at Lincoln this 11th day of February in the year of our Lord 1911, of the Independence of the United States the one hundred and thirtyfourth and of this State the forty-third.

"ADDISON WAIT, "Secretary of State."

Similar proceedings having been taken in three-fourths of the states, the formal process of adoption of the amendment was concluded by the proclamation of the Secretary of State as follows:

"PHILANDER C. KNOX,

"Secretary of State of the United States of America.

"To all whom these presents may come, Greeting:

"Know ye that, the Congress of the United States at the first session sixty-first Congress, in the year one thousand nine hundred and nine, passed a resolution in the words and figures following, to wit:

$$
\text { "'JOINT RESOLUTION. }
$$

"'Proposing an amendment to the Constitution of the United States.

"'Resolved by the Senate and House of Representatives of the United States of America in Congress assembled (two-thirds of each house con- 
common defence and general welfare of the United States; but all duties, imposts, and excises shall be uniform throughout the United States.' Art I, $\sec 8$, clause 1.

" '3. No capitation or other direct tax shall be laid, unless in proportion to the census or enumeration hereinbefore directed to be taken.' Art I, sec. 9, clause 5 .

"4. No tax or duty shall be laid on articles exported from any state.' Art. I, sec. 9, clause 5."

"Thus, in the matter of taxation," said Mr. Chief Justice Fuller, speaking for the Court in the same case, "the Constitution recognizes the two great classes of direct and indirect taxes, and lays

curring therein). That the following article is proposed as an amendment to the Constitution of the United States, which, when ratified by the legislatures of three-fourths of the several states, shall be valid to all intents and purposes as a part of the Constitution:

" "Article XVI. The Congress shall have power to lay and collect taxes on incomes, from whatever source derived, without apportionment among the several states, and without regard to any census or enumeration."

"And further, that it appears from official documents on file in this Department that the Amendment to the Constitution of the United States proposed as aforesaid has been ratified by the legislatures of the States of Alabama, Kentucky, South Carolina, Illinois, Mississippi, Oklahoma, Maryland, Georgia, Texas, Ohio, Idaho, Oregon, Washington, California, Montana, Indiana, Nevada, North Carolina, Nebraska, Kansas, Colorado, North Dakota, Michigan, Iowa, Missouri, Maine, Tennessee, Arkansas, Wisconsin, New York, South Dakota, Arizona, Minnesota, Louisiana, Delaware, and Wyoming, in all thirty-six.

" 'And, further, that the states whose legislatures have so ratified the said proposed amendment, constitute three-fourths of the. whole number of states in the United States.

"'And further, that it appears from official documents on file in this Department that the legislatures of New Jersey and New Mexico have passed resolutions ratifying the said proposed amendment.

"Now therefore, be it known that I, Philander C. Knox, Secretary of State of the United States, by virtue and in pursuance of Section 205 of the Revised Statutes of the United States, do hereby certify that the amendment aforesaid has become valid to all intents and purposes as a part of the Constitution of the United States.

"In Testimony Whereof, I have hereunto set my hand and caused the seal of the Department of State to be affixed.

"Done at the city of Washington this twenty-fifth day of February in the year of our Lord one thousand nine hundred and thirteen and of the Independence of the United States of America the one hundred and seventh.

"'PHILANDER C. KNOX.'” 
down two rules by which their imposition must be governed, namely: The rule of apportionment as to direct taxes, and the rule of uniformity as to duties, imposts and excises.

"The rule of uniformity was not prescribed to the exercise of the power granted by the first paragraph of section eight, to lay and collect taxes, because the rule of apportionment as to taxes had already been laid down in the third paragraph of the second section.

"And this view was expressed by Mr. Chief Justice Chase in The License Tax Cases, 5 Wall., 462, 471, when he said: 'It is true that the power of Congress to tax is a very extensive power. It is given in the Constitution, with only one exception and only two qualifications. Congress cannot tax exports and it must impose direct taxes by the rule of apportionment, and indirect taxes by the rule of uniformity. Thus limited, and thus only, it reaches every subject, and may be exercised at discretion." "2

The case of Pollock v. Farmers' Loan \& Trust Co. came before the Supreme Court on appeal from the Circuit Court of the United States for the Southern District of New York, where a bill had been filed by a stockholder of the Trust Company to restrain it from voluntarily complying with the provisions of an act of Congress passed August 15, 1894, and designed to provide revenue through a tax upon incomes. It was contended that the income tax sought to be imposed was a measure essentially direct in its nature, as the term direct is used in the Constitution; hence to comply with the constitutional provisions above cited, it would be necessary to apportion such a tax among the states as representatives in Congress are apportioned pursuant to the Federal census. This had manifestly not been done, since the tax levied was intended to fall on incomes of certain classes wherever found and throughout the country without regard to proportionate amounts being raised in the several states in accordance with their respective populations. In any case, it was argued, the plan must be at variance with the Constitution since, as will appear from the summary of the law in the margin, ${ }^{3}$ certain classes of

2157 U. S., 429-613.

3 In the statement prefixed to the reported case the measure is thus, in part, summarized: "By sections 27 to 37 inclusive of the Act of Congress entitled, 'An act to reduce taxation, to provide revenue for the Government, and for other purposes,' received by the President August 15, 1894, and which, not having been returned by him to the House in which it originated within the time prescribed by the Constitution of the United 
income were expressly exempted from the operation of the statute, and this, it was insisted, ran counter to the constitutional regulation that duties, imposts and excises (as constrasted with direct taxes) be levied by the rule of uniformity; again, incomes drawn from certain sources ${ }^{4}$ were made liable to taxation where

States, became a law without approval (28 Stat. 509, C. 349), it was provided that from and after January 1, 1895, and until January 1, 1900, 'there shall be assessed, levied, collected, and paid annually upon the gains, profits, and income received in the preceding calendar year by every citizen of the United States, whether residing at home or abroad, and every person residing therein, whether said gains, profits, or income be derived from any kind of property, rents, interest, dividends, or salaries, or from any profession, trade, employment, or vocation carried on in the United States or elsewhere, or from any other source whatever, a tax of two per centum on the amount so derived over and above four thousand dollars, and a like tax shall be levied, collected, and paid annually upon the gains, profits, and income from all property owned and of every business, trade, or profession carried on in the United States by persons residing without the United States." " (157 U. S., 434.)

"On the first hearing the Court said: "The contention of the complainant is :

First: That the law in question, in imposing a tax on the income or rents of real estate, imposes a tax upon the real estate itself; and in imposing a tax on the interest or other income of bonds or other personal property held for the purposes of income or ordinarily yielding income, imposes a tax upon the personal estate itself; that such tax is a direct tax, and void because imposed without the regard to the rule of apportionment; and that by reason thereof the whole law is invalidated.

Second: That the law is invalid, because imposing indirect taxes in violation of the constitutional requirement of uniformity; and therein also in violation of the implied limitation upon taxation that all tax laws must apply equally, impartially and uniformly to all similarly situated. Under the second head it is contended that the rule of uniformity is violated in that the law taxes the income of certain corporations, companies, and associations, no matter how created or organized, at a higher rate than the incomes of individuals or partnerships derived from precisely similar property or business; in that it exempts from the operation of the act and from the burden of taxation, numerous corporations, companies, and associations having similar property and carrying on similar business to those expressly taxed; in that it denies to individuals deriving their income from shares in certain corporations, companies, and associations the benefit of the exemption of $\$ 4,000$ granted to other persons interested in similar property and business; in the exemption of building and loan associations, savings banks, mutual life, fire, marine, and accident insurance companies, existing solely for the pecuniary profit of their members; these and other exemptions being alleged to be purely arbitrary and capricious, justified 
the source itself would appear to militate against the constitutional validity of such a measure. Even were the law of 1894, therefore, to be construed as providing not a direct system of taxation but one to take effect by way of excise or duty merely, the scheme would still fall under the ban of unconstitutionality as being plainly not uniform in certain phases of its operation. The trust company's cause was twice argued. since at the first hearing the Justices were divided in opinion on several important points at issue; these were finally determined at the rehearing May 20, $1895,{ }^{5}$ with the result that the attempt by Congress to tax income

by no public purpose, and of such magnitude as to invalidate the entire enactment; and in other particulars.

Third: That the law is invalid so far as imposing a tax upon income received from state and municipal bonds. (157 U. S., 555.)

${ }^{5}$ At the re-hearing the Chief-Justice in further explanation of the Court's attitude, added: "Our previous decision was confined to the consideration of the validity of the tax on the income from real estate, and on the income from municipal bonds. The question thus limited was whether such taxation was direct or not, in the meaning of the Constitution; and the Court went no farther, as to the tax on the income from real estate, than to hold that it fell within the same class as the source whence the income was derived, that is, that a tax upon the realty and a $\operatorname{tax}$ upon the receipts therefrom were alike direct; while as to the income from municipal bonds, that could not be taxed because of want of power to tax the source, and no reference was made to the nature of the tax as being direct or indirect.

We are now permitted to broaden the field of inquiry, and to determine to which of the two great classes a tax upon a person's entire income, whether derived from rents, or products, or otherwise, of real estate, or from bonds, stocks, or other forms of personal property, belongs; and we are unable to conclude that the enforced subtraction from the yield of all the owner's real or personal property, in the manner prescribed, is so different from a tax upon the property itself, that it is not a direct, but an indirect tax, in the meaning of the Constitution." (158 U. S., 618.)

The final results reached in these causes revealed much divergence of opinions among the Justices; the views which were shared by a strong minority of the Court are forcibly indicated by Mr. Justice, now Mr. Chief Justice White, in his dissenting opinion (159 U. S., 710) :

"The decision here announced holding that the tax on the income from real estate and the tax on the income from personal property and investments are direct, and therefore require apportionment, rests necessarily on the proposition that the word 'direct' in the Constitution must be construed in the economic sense; that is to say, whether a tax be direct or indirect is to be tested by ascertaining whether it is capable of being shifted from the one who immediately pays it to an ultimate consumer. If it cannot be so shifted, it is direct; if it can be, it is indirect. But the word in this sense applies not only to the income from real estate and 
completely failed, the Court holding that a tax falling on the income of real and personal estate is essentially a direct tax within the meaning of the Constitution, and as it is plainly a tax levied on gains belonging to individuals or corporations generally and not apportioned among the states in accordance with their representation in Congress, it cannot be sustained.

By apportionment in accordance with the census there was intended a plan to require from each state such a proportion of a proposed tax laid by the National Government as the number of representatives elected in that state to. Congress should bear to the total number at the moment credited to the House of Representatives. The term direct tax was not, when the Constitution was drawn, attempted to be either precisely or finally defined, nor, in view of the amendment which now removes this vexed question from the courts, does it seem likely that we shall ever

personal property, but also to business gains, professional earnings, salaries, and all of the many sources from which human activity evolves profit or income without invested capital. These latter the opinion holds to be taxable without apportionment, upon the theory that taxes on them are 'excises' and, therefore, do not require apportionment according to the previous decisions of this court on the subject of income taxation. These decisions, Hylton v. United States, 3 Dall., 171; Pacific Insurance Co. v. Soulé, 7 Wall., 433 ; Veazie Bank v. Fenno, 8 Wall., 533; Scholey v. Rew, 23 Wall., 331 ; Springer v. Unitcd States, 102 U. S., 586, hold that the word 'direct' in the Constitution refers only to direct taxes on land, and therefore has a constitutional significance wholly different from the sense given to that word by the economists. The ruling now announced overthrows all these decisions. It also subverts the economic signification of the word 'direct' which it seemingly adopts. Under that meaning, taxes on business gains, professional earnings, and salaries are as much direct, and, indeed, even more so, than would be taxes on invested personal property. It follows, I submit, that the decision now rendered accepts a rule and at once in part overthrows it. In other words, the necessary result of the conclusion is to repudiate the decisions of this court, previously rendered, on the ground that they misinterpreted the word 'direct', by not giving it its economic sense, and then to decline to follow the economic sense because of the previous decisions. Thus the adoption of the economic meaning of the word destroys the decisions, and they in turn destroy the rule established. It follows, it seems to me, that the conclusion now announced rests neither upon the economic sense of the word 'direct' or the constitutional significance of that term. But it must rest upon one or the other to be sustained. Resting on neither, it has, to my mind, no foundation in reason whatever." (Compare, also, the dissenting opinion of the same Justice, with whom concurred Mr. Justice Harlan, 157 U. S., page $608,636$. 
agree upon a consistent interpretation of the expression in its constitutional acceptation.

It was, however, but a short period after the inception of government under the Constitution that Congress (June 5th, 1794, U. S. Statutes at Large, p. 373) laid a tax of ten dollars on each pleasure-carriage in the country and without provision for an apportionment of the tax among the several states in accordance with the population. Payment being resisted by one Hylton, the case came before the Supreme Court on writ of error from the United States Circuit Court in Virginia, where Mr. Justice Wilson (of the United States Supreme Court) and District Judge Griffin were divided in opinion on the constitutional point. ${ }^{6}$ Hamilton, who as Secretary of the Treasury, had proposed the carriage tax, argued the case for the Government; Marshall, later Chief Justice, being of counsel (though his name does not appear on the record) with the plaintiff in error. Without attempting an authoritative definition of the term direct tax, the Justices were content to consider the measure before them as not a direct imposition but as an excise or duty,-a carriage being a consumable commodity; since the tax, then, was not direct there was no need for its apportionment and it would doubtless fall uniformly upon its objects throughout the country. It is quite evident, however, that the court did implicitly lean to the construction that direct taxes in the minds of those who had approved the Constitution some eight years only earlier, must probably comprise no taxes other than capitation taxes, or taxes on land; thus by a process of exclusion the carriage tax might well be held an excise, and, similarly, the court in later years more readily adopted the conclusion (when, at the Civil War era, income taxation came up for interpretation) that Congress was not debarred from taxing incomes without apportionment since such a tax, being neither a capitation nor yet a land tax cannot come within the purview of

B 3 Dallas, 174; compare, also, the remarks of Iredell, J., at p. 181-2. "It appears to me," said Mr. Justice Chase, "that a tax upon carriages cannot be laid by the rule of apportionment without very great inequality and injustice. For example, suppose two states equal in census to pay eighty thousand dollars each by a tax on carriages of eight dollars on every carriage; and in one state there are one hundred carriages, and in the other one thousand. The owners of carriages in one state would pay ten times the tax of owners in the other. A, in one state, would pay for his carriage eight dollars; but $B$, in the other state, would pay for his carriage eighty dollars." 
necessary apportionment but should fall by way of an excise. On many occasions, indeed, Congress saw fit to levy a direct and apportioned tax as well as an income tax; measures of this latter character being uniformly, until the Pollock case, sustained by the Court. In this latier case, in which the arguments were of the same elaborate nature which had characterized the preceding cause of Pacific Insurance Company v. Soule, the Justices, though not unanimously, adjudged, as we have seen, the tax to be direct; hence it did not become necessary to define the term uniformity. Fortunately, this was done four years later in the leading case of Knozolton v. Moore, ${ }^{7}$ in construing the War Revenue Act of June 13, 1898: "As the term uniform is employed in Section 8, Article $\mathrm{I}$, of the Constitution," said the Justices, "a geographical uniformity merely is intended." "On the one side," said Mr. Justice, now Mr. Chief Justice White, speaking for the court, "the proposition is that the command that duties, imposts and excises shall be uniform throughout the United States relates to the inherent and intrinsic character of the tax; that it contemplates the operation of the tax upon the property of the individual taxpayer, and exacts that when an impost, duty or excise is levied, it shall operate precisely in the same manner upon all individuals; that is to say, the proposition is that 'uniform throughout the United States' commands that excises, duties and imposts, when levied, shall be equal and uniform in their operation upon persons

7178 U. S., 41, 82 (Knowlton v. Moore) : "*** in the income tax cases the theory of certain economists by which direct and indirect taxes are classified with reference to the ability to shift the same was adverted to. But this disputable theory was not the basis of the conclusion of the Court. The Constitutional meaning of the word 'direct' was the matter decided. Considering that the constitutional rule of apportionment had its origin in the purpose to prevent taxes on persons solely because of their general ownership of property from being levied by any other rule than that of apportionment, two things were decided by, the Court: First, that no sound distinction existed between a tax levied 'on a person solely because of his general ownership of real property, and the same tax imposed solely because of his general ownership of personal property. Secondly, that the tax on the income derived from such property, real or personal, was the legal equivalent of a direct tax on the property from which said income was derived, and hence must be apportioned."

Congress has on many occasions during the first century of government under the Constitution levied a direct and apportioned tax (157 U. S., p. 572-3); as well as taxes on incomes which taxes were, in a series of noted cases, sustained by the Supreme Court; Mr. Justice, now Mr. Chief Justice White, enumerates them in 157 U. S., at page 626. 
and property in the sense of the meaning of the words equal and uniform, as now found in the constitutions of most of the states of the Union. The contrary construction is this: That the words 'uniform throughout the United States' do not relate to the inherent character of the tax as respects its operation on individuals, but simply requires that whatever plan or method Congress adopts for laying the tax in question, the same plan and the same method must be made operative throughout the United States; that is to say, that whenever a subject is taxed anywhere, the same must be taxed everywhere throughout the United States, and at the same rate. The two contentions then may be summarized by saying that the one asserts that the Constitution prohibits the levy of any duty, impost or excise which is not intrinsically equal and uniform in its operation upon individuals, and the other that the power of Congress in levying the taxes in question is by the terms of the Constitution restrained only by the requirement that such taxes be geographically uniform. *** (p. 89.) Now, that the requirement that direct taxes should be apportioned among the several states, contemplated the protection of the states, to prevent their being called upon to contribute more than was deemed their due share of the burden is clear. Giving to the term uniformity as applied to duties, imposts and excises a geographical significance, likewise causes that provision to look to the forbidding of discrimination as between the states, by the levying of duties, imposts or excises upon a particular subject in one state and a different duty, import or excise on the same subject in another; and therefore, as far as may be, is a restriction in the same direction and in harmony with the requirement of apportionment of direct taxes. And the conclusion that the possible discrimination against one or more states was the only thing intended to be provided for by the rule which uniformity imposed upon the power to levy duties, imposts and excises, is greatly strengthened by considering the state of the law in the mother country and in the colonies and the practice of taxation which obtained at or about the time of the adoption of the Constitution."

While the determination in the Pollock cause was made by a court far from unanimous in its findings, it was clearly seen that the judgment must mark, for a long period in any event, the attitude of the Supreme Court toward income taxation on the part of Congress in so far, at least, as the creation of any taxation plan which might be deemed at all practicable could be concerned. 
That taxes on incomes are essentially direct, that they cannot be laid irrespective of the source whence income may be derived, that as being direct they must be apportioned among the states as representation in Congress is apportioned;-these points clearly appear as the final decision of our highest tribunal. Accordingly, a well-defined sentiment in favor of a constitutional amendment which would squarely met the defects judicially found in the Act of 1894 having appeared in many parts of the country, President Taft, in a special message to the Sixty-first Congress (June 16th, 1909) recommended, as has been noted, the adoption of a resolution to amend the Constitution in this regard. July 31st, 1909, such a concurrent resolution having been adopted by both Houses, was deposited with the Secretary of State, and, subsequently meeting confirmation in three-fourths of the state legislatures, was in due course announced by the Secretary, as part of the fundamental law. While thus the constitutional problems surrounding income taxation have proved sufficiently perplexing, their study but renders clear the inevitable difficulties. which must arise when economic aims are sought to be worked out through constitutional forms. That along lines deemed indispensable to financial welfare Congress has now been granted ample power, though in a well-defined path, gives the best assurance possible that our form of government in its broad outlines and with no change in its essential spirit will ever be found equal to the country's needs.

Widely removed in character from the Sixteenth Amendment, the Seventeenth, while effecting no organic change in the structure of our national legislature, goes, nevertheless, much farther than the mere removal of a restriction upon congressional legislative power. It is now not the capacity nor yet the extent of legislative activity that is sought to be controlled, but it is the source itself whence a branch of the legislature is derived which finds itself subjected to most important alterations; the Senate springing heretofore from the choice of state legislatures is hereafter to rest directly upon popular vote in each state and will thus stand politically upon the same basis as the House of Representatives.

The text of the Constitution provides that

"The Senate of the United States shall be composed of two Senators from each State, chosen by the Legislature thereof, for six years; and each Senator shall have one vote. *** 
"The times, places and manner of holding Elections for Senators and Representatives, shall be prescribed in each State by the Legislature thereof; but the Congress may at any time by law make or alter such Regulations, except as to the places of chusing Senators."

Such was the method of selecting our Second Chamber finally determined upon in 1787, though not without much debate and the consideration of other plans: that of Mr. Randolph ${ }^{8}$ looked to the selection of the second branch by the members of "the first, out of a proper number of persons nominated by the individual legislatures": George Read, of Delaware, thought

"That the Senate should be appointed, by the executive magistrate, out of a proper number of persons to be nominated by the individual legislatures. He said, he thought it his duty to speak his mind frankly. Gentlemen, he hoped, would not be alarmed at the idea. Nothing short of this approach towards a proper model of government, would answer the purpose, and he thought it best to come directly to the point at once. His proposition was not seconded nor supported $;$

\section{Wilson}

"opposed both a nomination by the state legislatures, and an election by the first branch of the national legislature, because the second branch of the latter ought to be independent of both. He thought both branches of the national legislature ought to be chosen by the people, but was not prepared with a specific proposition. He suggested the mode of choosing the Senate of New York-to wit, of uniting several election districts for one branch, in choosing members for the other branch, as a good model."10

\section{R. D. Spaight}

"contended, that the second branch ought to be chosen by the state legislatures, and moved an amendment to that effect."

The latter plan ultimately found support which rendered it victorious.

"This combination," said Dickinson, "of the state governments with the national government was as politic as it was unavoidable. In the formation of the Senate, we ought to carry it through such a refining process as will assimilate it, as nearly as may be, to the House of Lords in England." He repeated his warm eulogiums on the British constitution. He was for a strong national gov-

8 Elliott's Debates, vol. 5, 127.

Ibid., p. 167.

10 Ibid., p. 138.

${ }^{11}$ Ibid., p. 137. 
ernment, but for leaving the states a considerable agency in the system. The objection against making the former dependent on the latter might be obviated by giving to the Senate an authority permanent, and irrevocable for three, five or seven years. Being thus independent, they will check and decide with uncommon freedom. ${ }^{\text {:2 }}$

A legislative choice, accordingly, was comprised in Gorham's report made June 13th, and in that of the Committee of Detail, July 26th, and so took its final place in the Constitution as signed on September 17, 1787, ${ }^{13}$ and, in accordance with the general plan under which the new government was to begin its existence, the state legislatures in the winter of the following year, chose the first senators. Here for the next thirty-five years the matter practically rested, although the divergence of opinion so clearly shown in the convention was destined to take advantage of the opportunity offered, when Congress during the term of President John Quincy Adams found itself besieged with propositions to modify the method of electing the President, to once more make itself known in a definite motion for the abolition of legislative election of senators and the substitution therefor of the popular choice. ${ }^{14}$ From that period until the present day similar motions have been offered in both branches of Congress, and though favored by the House of Representatives, were persistently opposed by the Senate itself, whose attitude on this all-important question of its own derivation exhibited an attitude of essentially vicious reaction, demonstrating in a most regrettable fashion that the Senate had totally failed to grasp one of the leading conceptions of those who made the Constitution, namely, that this great instrument came inevitably from the hands of its framers fraught, in many aspects, with the results not of conclusive wisdom, but of a spirit of compromise deemed inclispensable if the proposed plan of government was to be approved by each one of the states of the Confederation. Nothing, indeed, may be saicl to be more thoroughly unconstitutional than to ascribe conceptions of finality to the Constitution itself. On the contrary, the provisions contained in it for its own alteration, as well as the utterances of its contem-

12 Ibid., p. 163.

13 Ibid., p. 189, 375-7, 559.

1 : Proposed in 1826 by Mr. Storrs of New York, in the House. (Ames, "The Proposed Amendments to the Constitution of the United States During the First Century of Its History," Annual Report of the American Historical Association for 1896, vol. 2, pp. 61, 340.) 
porary advocates, prove conclusively that change was to be expected and must come. ${ }^{15}$ The true measure of our constitutional plan should take large account of its essential flexibility rather than of its apparent rigidity whenever public opinion imperatively calls for new. provisions at the expense of those outworn or no longer in harmony with present-day needs.

Article $V$ of the Constitution declares that

"The Congress, whenever tw.o-thirds of both Houses shall deem it necessary, shall propose amendments to this Constitution, or, on the application of the Legislatures of two-thirds of the several States, shall call a Convention for proposing amendments, which, in either case, shall be valid to all Intents and Purposes, as Part of this Constitution, when ratified by the Legislatures of threefourths of the several States, or by Conventions in three-fourths thereof, as the one or the other Mode of Ratification may be proposed by the Congress; Provided that no Amendment which may be made prior to the Year. One thousand eight hundred and eight shall in any Manner affect the first and fourth Clauses in the Ninth Section of the first Article; and that no State, without its Consent, shall be deprived of its equal Suffrage in the Senate."

Unider this article amendments have been adopted at four periods of our constitutional history, the first ten amendments, however, being cotemporary with the beginning of government under the new Constitution. ${ }^{16}$ These amendments being but fifteen in all, would seem to argue an inherent difficulty besetting constitutional change if we consider the appalling number of aterations which have been proposed: ${ }^{17}$ Nevertheless, the adop-

15 "The novelty and difficulty of the experiment," said Gerry, speaking in the Convention, June 5, 1787, "requires periodical revision. The prospect of such a revision would also give intermediate stability to the Government." (Elliott's Debates, 5, 157.) To multiply similar citations from the-records of the time would be unnecessary. Compare Hamilton's remarks in 5 Elliott, p. 531.

16 The first ten amendments were proposed by Congress Sept. 25, 1789, and declared in force Dec. 15, 1791; the eleventh, January 8, 1798; the twelfth, Sept. 25, 1804; the thirteenth, Dec. 18, 1865; the fourteenth, July 28, 1868; the fifteenth, March 30,1870 . The last three being usually classed together as the Civil War amendments, although proposed and ratified at different times. About the same interval, however, elapsed between the decision of the Chisholm case in the Supreme Court (Feb. 18, 1793) and the final adoption of the eleventh amendment, Jan. 8, 1798, as we find between the close of the war in the spring of 1865 and the adoption of the fifteenth amendment March 30, 1870.

17 Prof. Ames, loc. cit., enumerates some 1736; his list was made up for his notable prize essay in 1897 . The long-continued failure to achieve 
tion of the two latest ones, as well as circumstances attending the ratification of those which preceded them, alike demonstrate that once the needed change has found a sufficiently widespread following to justify it as an expression of popular will, the Constitution itself contains all the needed mechanism to render such a change effective. We have, indeed, not yet exhausted the latent possibilities in this regard of our fundamental instrument. Hitherto, constitutional change has come about through congressional initiative and a ratification by the necessary number of state legislatures; but as the text above quoted shows, it is competent for two-thirds of the state legislatures to demand at the hands of Congress a national convention at which amendments. may be proposed, subject to ratification by the state legislatures or state conventions, as may be indicated by Congress. We have here, in the Constitution's own text, it is to be noted, the essential principle not merely of a legislative but of a popular initiative and referendum, as, it may be said in passing, that of the recall appears in the earlier Articles of Confederation. ${ }^{18}$ Under the article touch-

the adoption of an amendment changing the method of senatorial choice led several states to devise plans through which a practically popular selection might be made on lines marked out by the direct-primary principle or by convention instructions. In his comprehensive address in the Senate, May 5, 1910, Senator Bourne has clearly sketched the Oregon plan; Senator Nelson, of Minnesota, summarized this new feature in the Senate Feb. 20, 1911.

18 Article $V$ of the Articles of Confederation provides "a power reserved to each state to recall its delegates or any of them, at any time within the year, and to send others in their stead for the remainder of the year." It was proposed on June 24,1788 , to introduce this feature into the National Constitution. In the celebrated Constitution reported to the French National Convention June 10, 1793, by Hérault de Séchelles and approved June 24 and ratified in a plebiscititm by overwhelming majorities, thè popular referendum is carefully embodied. We have here the working out of the Rousseau-Löcke conceptions of control by the true sovereign which had found expression in the constitutional-amendinent clauses of our own Constitution and which owed their existence to the same inspifation. Section 58-60 of the Séchelles (or Montagnard) Constitution provide: "Le projet (de loi) est imprimé et envoyé a toutes les communes de la Républiquue, sous ce titre; loi proposée. Quarante jours aprés l'envoi de la loi proposée si daus la moitié des départements, plus un, le dixième des assemblées primaires de chacun d'eux, régulièrement formées, n'a pas réclamé, le projet est accepté et devient loi.

"S'il y a réclamation, le corps législatif convoque les assemblées primaries." (Duguit et Monnier, Les Constitutions, etc., de la France, p. 72.)

10 Congressional control under the Constitution is fully reviewed in the case of James $v$. Bowman, 190 U. S., 127, decided May 4, 1903. 
ing amendments indeed it has been found possible recently to bring to bear upon Congress a pressure whose primal impulse springs from true popular initiative only a little less fully developed than is this principle in the most advanced political thought of our own day. For although Congress has not as yet been asked by the requisite number of states to call a popular convention for amending the Constitution, it is yet undeniable that the appearance in some parts of the country of a determination to effect a change in the method of senatorial selection through this means if the more customary channels were to fail, has proved no small element in stirring congressional consciousness to a sense of its duty and in bringing it to the point where this most ardentlydesired measure has finally passed into fundamental law. In this connection the resolution of Illinois is most significant, and we cite it in full:

\section{STATE OF ILLINOIS. Department of State.}

To All to Whom These Presents Shall Come, Greeting:

I, James A. Rose, secretary of state of the State of Illinois,

The following is the text of the Secretary of State's Proclamation announcing the adoption of the Seventeenth Amendment:

"William Jennings Bryan,

"Secretary of State of the United States of America.

"To all to whom these presents may come, Greeting:

"Know Ye that, the Congress of the United States at the second session, sixty-second Congress, in the year one thousand nine hundred and twelve, passed a resolution in the words and figures following: to wit:

"'Joint Resolution

'Proposing an amendment to the Constitution providing that senators shall be elected by the people of the several states.

"'Resolved by the Senate and House of Representatives of the United States of America in Congress assembled (two-thirds of each house concurring therein), That in lieu of the first paragraph of section 3 of Article I of the Constitution of the United States, and in lieu of so much of paragraph 2 of the same section as relates to the filling of vacancies, the following be proposed as an amendment to the Constitution, which shall be valid to all intents and purposes as part of the Constitution when ratified by the legislatures of three-fourths of the states:

" "The Senate of the United States shall be composed of two senators from each state, elected by the people thereof, for six years; and each senator shall have one vote. The electors in each state shall have the qualifications requisite for electors of the most numerous branch of the state legislatures.

" "When vacancies happen in the representation of any state in the Senate, the executive authority of such state shall issue writs of election 
do hereby certify that the following and hereto attached is a true copy of Senate joint resolution No. 5 of the forty-third general assembly, adopted by the Senate February 10, 1903, and concurred in by the House April 9, 1903, the original of which is now on file and a matter of record in this office.

In testimony whereof, I have hereto set my hand and caused to be affixed the great seal of State. Done at the city of Springfield this 10th day of March A. D. 1908.

JAMES A. ROSE, Secretary of State.

Whereas by direct vote of the people of the State. of Illinois at a general election held in said State on the 4th day of November A. D. 1902, it was voted that this general assembly take the necessary steps under Article V of the Constitution of the United States to bring about the election of United States Senators by direct vote of the people; and

to fill such vacancies: Provided, That the legislature of any state may empower the executive thereof to make temporary appointment until the people fill the vacancies by election as the legislature may direct.

" " "This amendment shall not be so construed as to affect the election or term of any senator chosen before it becomes valid as part of the Constitution."

" "And, further, that it appears from official documents on file in this Department that the Amendment to the Constitution of the United States proposed as aforesaid has been ratified by the legislatures of the States of Massachusetts, Arizona, Minnesota, New York, Kansas, Oregon, North Carolina, California, Michigan, Idaho, West Virginia, Nebraska, Iowa, Montana, Texas, Washington, Wyoming, Colorado, Illinois, North Dakota, Nevada, Vermont; Maine, New Hampshire, Oklahoma, Ohio, South Dakota, Indiana, Missouri, New Mexico, New Jersey, Tennessee, Arkansas, Connecticut, Pennsylvania, and Wisconsin.

"And, further, that the states whose legislatures have so ratified the said proposed amendment, constitute three-fourths of the whole number of states in the United States.'

"Now, therefore, be it known, that I, William Jennings Bryan, Secretary of State of the United States, by virtue and in pursuance of Section 205 of the Revised Statutes of the United States, do hereby certify that the amendment aforesaid has become valid to all intents and purposes as a part of the Constitution of the United States.

"In testimony whereof, I have hereunto set my hand and caused the seal of the Department of State to be affixed.

"Done at the city of Washington this thirty-first day of May in the year of our Lord one thousand nine hundred and thirteen, and of the Independence of the United States of America the one hundred and thirtyseventh.

(Seal)

"WILLIAM JENNINGS BRYAN." 
Whereas Article V of the Constitution of the United States provides that on the application of the legislatures of two-thirds of the several States the Congress of the United States shall call a convention for proposing amendments; Now, therefore, in obedience to the expressed will of the people as expressed at the said election, be it

Resolved by the Senate (the House of Representatives concurring herein), That application be, and is hereby made to the Congress of the United States to call a convention for proposing amendments to the Constifution of the United States, as provided for in said Article V; and be it further

Resolved, That the secretary of state do furnish to the President of the Senate of the United States and to the Speaker of the House of Representatives of the United States, to each, one copy of this resolution, properly certified.under the great seal of the State.

Adopted by the Senate February 10, 1903.

J. H. PADDOCK, Secretary of the Senate.

Concurred in by the House, April 9, 1903.

W. A. NORTHCOTT, President of the Senate.

JNO. A. REEVE,

Clerk of the House of Representatives.

JOHN H. MILLER,

Speaker of the House of Representatives..

This resolution and others of similar nature were collected and with appropriate resolutions for amendment of the Constitution, comprising five separate articles, were presented to Congress on the part of the Governor of Oklahoma and ordered to be printed,

April 30, 1908.

"The action of twenty-seven States of the Union," says the memorial, "in requesting a convention of the States must impress the Congress that patience has almost ceased to be a virtue and that Congress has not listened with even diligence and justice to the source of all power-the people of our country."

The memorial proposed the following:

Resolved by the Senate and House of Representatives of the United States of America in Congress Assembled (two-thirds. of both houses concurring), That the following articles be propased to the legislature of the several States as amendments to the Constitution of the United States, all or any of which articles, when ratified by three-fourths of the State legislatures, to be valid to all intents and purposes as part of the said Constitution, viz: 
Article 16. The Senate of the United States shall be composed of two Senators from each State, chosen by the electors thereof for six years, and each Senator shall have one vote; and the electors in each State shall. have the qualifications requisite for electors of Members of the House of Representatives. They shall be divided as equally as may be into three classes, so that onethird may be chosen every second year; and if vacancies happen, by resignation, or otherwise, the Governor may make temporary appointments until the next regular election in such State. No person shall be a Senator who shall not have attained the age of thirty years, and been nine years a citizen of the United States, and who shall not, when elected, be an elector of the State for which he shall be chosen. The Vice-President of the United States shall be President of the Senate, but shall have no vote unless they be equally divided. The Senate shall choose their own officers, and also a president pro tempore in the absence of the Vice-President, or when he shall exercise the office of the President of the United States.

Article 17. The Congress shall have power to provide for the collection of a uniform tax upon the gains, profits and income received by every citizen of the United States, including every corporation, association, or company doing business for profit in the United States, subject to such exemption as it may deem proper.

Article 18. The Congress shall have power to define and regulate the liability of common carriers engaged in interstate or foreign commece to their servants or employees for injuries resulting from the negligence of fellow-servants or co-employees.

Article 19. No State shall be denied the right to regulate the charges of common carriers for the carriage of freight or passengers wholly within the State or to regulate or prohibit the consolidation or combination of competing carriers.

Article 20. No State shall be denied the right to regulate or prohibit the shipment into the State of any article or articles of commerce injurious to public health or morals, or the product in whole or in part of convict labor.

Of the constitutional points aimed to be covered by these five propositions; two have now passed into our fundamental law, while Eongress, in its own legislation, has endeavored to compass important aspects of the remaining three. It may here be remarked that the concurrent resolution of the Senate and House of Representatives contemplated by the Constitution as one method of proposing amendments to the states differs in an important particular from the process of ordinary legislation in that the assent of the National Executive, witnessed by his signature, does not seem to be within the view of Article $V$ of the 
Constitution, as was determined by the Supreme Court, at February term, 1798, in the case of Hollingsworth $v$. Virginia. ${ }^{20}$

Shortly after the presenting of this memorial and on December 13,1909 , a resolution was introduced in the Senate which initiate: 1 the movement now brought to a successful conclusion for the transfer of senatorial elections to popular vote. Unfortunately, the motion became subsequently entangled with considerations looking to the annulment of congressional control in the proposed senatorial elections. Such a control had been authorized by virtue of the statutes passed in 1870-1871 and repealed in 1894, although this legislation was, properly speaking, a matter quite apart from the action contemplated on the part of Congress in Section 4, paragraph 1, of Article I, of the Constitution:

"The times, places and manner of holding elections for Senators and Representatives shall be prescribed in each State by the legislature thereof."

Under this constitutional clause Congress has undertaken to regulate, though not in large measure, senatorial elections (Act of July 25,1866 ) ; but the legislation of $1870-1871$ was passed to enforce provisions of the Fourteenth Amendment and dealt with phases of the subject now largely faded from the political horizon. But the Senate developed a strong leaning toward exclusion of possible congressional supervision in senatorial elections by poptlar vote should this plan come into operation, and much time was wasted in clearing the supposed difficulties attaching to this view of the matter. It was argued, and not without force, that whereas as the Constitution stood Congress had an undoubted right to regulate aspects of elections for both senators and representatives; but that since the senators were chosen by state legislators whose own election had been a matter only of state control and in nowise liable to congressional intervention, it would be quite a different matter to now suffer Congress to intervene in election by popular vote of the Senate,-there would be a difference, in fine, between the existing possibility of control in direct vote for representatives and in the proposed possibility of control in the choice of senators by popular vote, regard being had to the original constitutional clause vesting choice of senators in legislators whose election, as has been said, was wholly free from congressional interference.

${ }^{20} 3$ Dallas, 378, 381, note by Chase, J. 
Despite, however, such considerations, the proposition to merely transfer the power of electing senators from state legislatures to the votes of citizens at the polls, congressional power of control being left as at present existent in the Constitution, at length passed victoriously (June 12, 1911, in the Senate, and May 12, 1912, in the House), through both branches of Congress (the Sutherland and Bristow amendments ${ }^{21}$ in the Senate, being the chief points about which differences of sentiment were rallied) and within a surprisingly short period received confirmation in the requisite constitutional number of state legislatures. While the senate as heretofore chosen has undeniably played a great part in our national history, both as the Second Chamber of the nation's legislature and as an administrative body of the first importance, it cannot, nevertheless, be denied that it developed a certain difficulty in dealing with both domestic and foreign affairs thought by many, and in many cases rightly thought, to be sharply at issue with the best convictions of the country. That through the new plan for its choosing, a plan which, as we have seen, was strongly favored when our national institutions came into being, the Senate will surely breathe a more robust atmosphere and show aims of politically broader compass and increased generosity of aspiration is not to be cloubted. It only remains, in fact, to declare by constitutional amendment a method of so changing the method of election of the National Executive that it may be made through direct agency of the popular will as expressed by citizens in their several states, sweeping away the sadly outworn mechanism of intervening presidential electors, to align our National Government with the truest ideals of what a government by the people should and must be. That this has been for such a long period reached through practices which embody the spirit of the desired reform while clinging ostensibly to the letter of what in reality has long since passed away, is a questionable tribute to the spirit of supposed conservatism characterizing us in public affairs.

The transformation of the national legislature into $a$ body springing in both branches from popular vote and thus depending wholly on the nation's will voices a movement in political thought

21 Compare a review of the amendment's progress through Congress in Senator Bristow's article, "Resolution for the Direct Election of Senators," published as Senate Document No. 666, 62nd Congress, 2nd Session, and the very able debates as reported in the Congressional Record for 1911, especially the remarkable address of Senator Nelson, Feb. 11, 1911. 
which has already found significant expression elsewhere. In Great Britain it is but two years since the momentous Parliament Act, 1911, was passed after a struggle almost precisely cotemporary with the final phases, as we have above noted them, of the efforts in our own Congress which resulted in the adoption of the Seventeenth Amendment. The leading features of the British parliamentary struggle are still fresh in all minds. The precise bearing, however, of the measure adopted through which British parliamentary legislation will hereafter be controlled, to all intents and purposes, by the votes of a House of Commons directly chosen, may best be stated in the words of the Act itself :

An Act to make provision with respect to the powers of the House of Lords in relation to those of the House of Commons, and to limit the duration of Parliament.

(1) If any Public Bill (other than a Money Bill or Bill containing any provision to extend the maximum duration of Parliament beyond five years) is passed by the House of Commons in three successive sessions (whether of the same Parliament or not), and, having been sent up to the House of Lords at least one month before the end of the session, is rejected by the House of Lords in each of those sessions, that Bili shall, on its rejection for the third time by the House of Lords, unless the House of Commons direct to the contrary, be presented to His Majesty and become an Act of Parliament on the Royal Assent being signified thereto, notwithstanding that the House of Lords have not consented to the Bill: Provided that this provision shall not take effect unless. two years have elapsed between the date of the second reading in the first of those sessions of the Bill in the House of Commons and the date on which it passes the House of Commons in the third of those sessions.

(2) When a Bill. is presented to His Majesty for assent in pursuance of the provisions of this section, there shall be endorsed on the Bill the cerfificate of the Speaker of the House of Commons signed by him that the provisions of this section have been duly complied with.

(3) A Bill shall be deemed to be rejected by the House of Lords if it is not passed by the Fouse of Lords either without amendment or with such amendment only as may be agreed to by both Houses.

In France a movement similar in some of its aims has lately become evident and it is proposed to modify the present highly complex method of electing the Senate in order to bring this 
dignified body more closely in touch with popular sentiment and thus avoid the sharp divergence of opinion now manifested in important affairs between the two houses of the French parliament. The. Senate consists of 300 members, of whom today all save two have been chosen in accordance with the modifications wrought by the Act of 1884 , which abolished the feature of lifesenatorship contained in the constitutional laws of 1875 . In that plan seventy-five members of the Senate were to hold office for life (viager), while two hundred and twenty-five were to be chosen in special electoral assemblies. The National Assembly itself chose the first seventy-five life-senators, and subsequently as these were removed by death their places were filled by the Senate through coöptation as organized under the new constitution; of the two remaining life-senators, one owes his election to the National Assembly, while the other was chosen by the Senate. Although, therefore, the French Senate has now practically ceased to have any characteristics associated with the conception of a close corporation, nevertheless the method of its choice is of a character in theory very far removed from the comparatively simple plan of direct election by the people characterizing the Chamber of.Deputies of 597 members. The electoral assembly which meets in each department in obedience to presidential decree on the expiration of the nine-year senatorial terms, is composed of: (1) delegates from the Communes of the department (the number of such delegates being apportioned by Act of Parliament, December 9, 1884, in accordance with the membership of the Communal Assemblies, and membership in these assemblies being, again, regulated by law of April 5, 1884, in accordance with the population of the Commune); (2) the members of the Chamber of Deputies at Paris representing the Department; (3) the delegates from the District Councils (arrondissements); and (4) delegates from the Councils-General of the Department, these latter being administrative assemblies in which the influence of the Prefect practically appointed by the Minister of the Interior is ever of the first importance. The Senate is divided into three classes by lot so that in about one-third of the 87 departments of France senatorial elections occur each three years, the last having taken place early in 1912; but, as in the American plan of senatorial choice by state legislatures, it has been found that the electors of the Senate are so far removed from the citizen-vote that their sympathies and those of their candidates tend to diverge 
sharply from.conceptions of popular needs as voiced in the Chamber of Deputies. The larger part of these senatorial electoral colleges must, of course, consist of the communal delegates; these delegates are very numerous, there being over 36,000 communes in France; the number of electors, in fact, meeting to choose a senator may be as high as 1,500 , although perhaps 1,000 might prove an average figure. Yet numerous as is such an assemblage, it is in no sense a popular meeting, nor is it controlled by the same considerations which are evident in the case of the deputies. It has, in truth, many of the traits found in an American state legislature, but is infinitely more unwieldy and intractable. While the familiar and highly important principle of "parliamentary government" as known and practiced in France is generally taken to mean that the Ministry of the day must depend for its existence on a sustained approval of its measure by the Chamber of Deputies, nevertheless in the pending struggle over the introduction of proportional representation into the plan of election of the Chamber, it is to an adverse vote on the part of the Senate that a recent collapse of the Ministry, March I8, 1913 , is due. Thus the Senate, scarcely at all amenable to popular will, may thwart governmental plans of the Miristry of the day, though the latter be supported by a strong majority in the Chamber of Deputies; it may thus practically block legislation with which it is not in sympathy, as well as overturn the Ministry. Some change seems urgently needed by which this reactionary feature of parliamentary structure may be effectively modified. ${ }^{22}$

22 The subject is treated in great detail by Prof. Barthélemy, of Montpellier and Paris, in an article contributed to the Revue de Droit Publique et de la Science Politique for April-June, 1913, pp. 371-410. Senatorial elections, as practically carried out to-day exhibit a triumph of those administrative principles bequeathed to France by Napoleon and elaborated by him from the régime of Louis XIV. Voting in the electoral assemblies summoned to the departmental capital by the Prefect on orders received from Paris are the senators themselves from the Department, the members of the departmental Conseil-Géneral (elected in the communes, each Canton choosing one for a six-year term), the members of the Conseils d'Arrondissement (each Canton in the Arrondissement choosing a member), and, lastly, the communal delegates chosen expressly by each communal council for the senatorial election; a commune of 500 inhabitants or less has a council of 10 members and may choose one delegate, a commune of 60,000 or more has a council of 36 and sends 24 delegates. Paris has its special privileges. Thus commune, canton, arrondissement, department, all vote under unified regulation. 
In the other polities which most nearly approximate our own (Switzerland and the German Empire) it does not seem probable that any change of the nature we have been considering is especially demanded. In Switzerland the Council of States (Ständerat) is chosen, pursuant to the revised Constitution of 1874 , in the several Cantons (each so-called whole Canton sending two, and half-Cantons ench sending one), as each of these states may determine; the actual method of choice being in part by cantonal legislatures, by cantonal citizens voting at the polls, and by choice of the picturesque and purely democratic institution of the yearly Landsgemeinde. No complaint is visible in Switzerland of the parliamentary body thus elected. The other branch of parliament, the Nationalrat, is chosen by popular vote in fecleral districts as is our own House of Representatives, and the two chambers work in fair harmony, representing people and states under the collective executive (Bundesrat) of seven, whose chairman is the annual President of the Confederation.

In Germany the Reichstag of 397 members springs from popular choice; beyond it, however, and practically controlling the destinies of the country, is the formidable Federal Council (Bundesrat) is composed of $5^{8}$ delegates appointed in fixed proportions by each of the 25 governments which form the Empire, and whose chairman is the Chancellor, head of the Prussian royal ministry and direct appointee of the Kaiser. This body is theoretically ever in session and no measure can become law without its sanction. Its existence stamps the Empire as monarchical, under such limitations, however, as may spring from a constitution one element in which is the popularly-chosen Reichstag. It is to be said, nevertheless, that while the Bundesrat is in its spirit as well as in some features of its practical structure a very precise reproduction of the Reichstag of the Romano-Germanic Empire, it does yet appear to correspond in such marked degree to the requirements of the complex government in which it is the controlling feature that there is no demand for its essential change. It has recently (I III) under a new constitution given to Alsace-Lorraine, added three members appointed by the Kaiser, thus bringing the Imperial Territory into an apparently closer touch with the central government. In any event, the Empire seems destined to be largely swayed by royal Prussia, whose ultra conservatism finds many an echo in German reverence for a paternal government, as well as for things of the past. That 
this is not incompatible with a highly prosperous and in many aspects well contented people, experience during the last quartercentury in Germany would seem to conclusively prove. Such change as that great Empire may next enact on the constitutional side must apparently come from a widening of membership in the Reichstag, thus giving many practically disfranchised sections of the population a voice in their country's legislative deliberations.

While our Sixteenth and Seventeenth constitutional amendments have brought organic law into harmony with new requirements, it is not to be forgotten that many problems in connection with both amendments still remain to be met and solved in the practical conduct of government. To decree that an income tax is permissible is yet a long way from the elaboration of a plan by the legislature which may prove at once practicable and efficient in results. Nor will the election of their senators by the people show complete freedom from some mesaure of difficulty or possible disappointment. Such problems are, however, far less embarrassing than are those of purely constitutional aspect. To enact legislation necessary to place the new order on a working basis as vacancies occur in the Senate through death, resignation, or expiration of the senatorial term is the immediate requirement. The constitutional provision embodied in the amendment touching temporary appointment to the Senate by the Governor through power granted to him by the legislature is not without its possible perplexities.

As has been above noted, one further organic change in our electoral plan is urgently required, although the unanimous assent of the country to a practical nullification of any choice on the part of presidential electors other than the candidates nominated by party conventions would seem to have in this respect effectively amended the Constitution. It is, nevertheless, more than fitting that the voters should in theory as well as in fact elect the President, nor is this incompatible, as pointed out by Governor Bald$w^{2 n^{23}}$ in his second inaugural message to the Connerticut legisla-

${ }_{23}$ "The same policy which led the framers of the Federal Constitution to interpose the legislature betwen the people and their choice of senators, induced them to adopt the device of electoral colleges for the choice of the president and vice-president. It was thought that the members of such a college would select the men for these positions with a careful consideration not to be expected from the people acting directly as a whole. Events have proved that this reasoning was fallacious. The electoral colleges in 
ture, with a preservation of the relative proportionate weight of the several states now fixed in the electoral college, thus giving to the people of the states the presidential franchise, while restricting the force of their vote on lines wisely laid down long ago in the National Constitution.

Yale University, October, 1913.

Gordon E. Sherman.

each state long since became for each of their members, merely an instrument for registering his formal choice of men previously selected by a national nominating convention of the political party to which he may belong. The original scheme was calculated for a thinly settled country, with few newspapers, an imperfect system of public education, no methods of rapid transportations by mechanical power, no telegraphs, and no telephones. Our modern facilities of inter-communication, the general advance in popular education, and the development of party government, have created new conditions, which have devitalized the office of a presidential elector. It is time to abolish it.

"The people of the United States can safely be trusted to do the electing themselves. They will have but a short ballot to deal with, in voting for president and vice-president. The leading candidates will be or will become well known characters, for whether put forward by party conventions or direct primaries, the public press will not fail to discuss very fully both the principles they stand for and the personal qualities which they possess.

"I recommend to you the adoption of a resolution, requesting Congress to propose an amendment to the Constitution, abolishing the device of presidential electors, and allowing all the electors in the several states to vote directly for president and vice-president; those who are the choice of a plurality of those voting in each state to. be credited with the same number of votes from that state as under the existing scheme. Connecticut, for instance, now entitled to cast seven votes; the only difference being that they would have been cast directly by the people for themselves. The provisions for the case of a failure of any person to obtain a majority of the votes so given by the several states, would be the same as now.

"In this simple way, a useless $\operatorname{cog}$ in our electoral machinery would be eliminated, and the power of selection vested where, under the conditions now existing, it properly belongs." 